\title{
IMPLEMENTASI TANGGUNGJAWAB SOSIAL INSTITUSI PENDIDIKAN TINGGI (Studi pada Politeknik Negeri Manado)
}

\author{
Hedy D. Rumambi \\ hedydr@yahoo.com \\ Jerry S. Lintong \\ Politeknik Negeri Manado
}

\begin{abstract}
The implementation of sustainable development into social responsibility of all Indonesian people are not only business entities but also non-profit organizations. This study aims to explore, to describe and to interpret the implementation of social responsibility Manado State Polytechnics. To understand these implementations need to know the underlying concept and activity reporting their social responsibilities. This research was conducted using qualitative methods. The data were collected through interviews, observation, study documents and literature. Analysis and interpretation of data is done by reducing the data, present data, interpret data and draw conclusions. The results of this study are Manado State Polytechnic become partners in the implementation of Bank Rakyat Indonesia's CSR and also be a performer in social responsibility activities. Social responsibility of polytechnic intended for internal parties such as lecturers and students and external parties such as society and environment. The social responsibility activities include social and environmental aspects which was done routinely every year, one of them through the realization of the third Tridharma namely community service, and some was not routine. Community service activities carried out in the form of physical, non-physical, training and social assistance. Manado State Polytechnic report their social responsibility activities through activity reports, use of funds reports, financial statements and government agencies performance accountability reports.
\end{abstract}

Key words: Social responsibility of higher education institutions, social responsibility activity, social responsibility activity report

\begin{abstract}
ABSTRAK
Terlaksananya pembangunan berkelanjutan menjadi tanggungjawab sosial seluruh masyarakat Indonesia tidak hanya entitas bisnis saja tetapi juga organisasi non profit. Penelitian ini bertujuan untuk menggali, mendeskripsikan dan menginterpretasi implementasi tanggungjawab sosial Politeknik Negeri Manado. Untuk memahami implementasi tersebut perlu diketahui konsep yang mendasari dan pelaporan aktivitas tanggungjawab sosialnya. Penelitian ini dilakukan dengan menggunakan metode kualitatif. Data-data dikumpulkan melalui wawancara, observasi, studi dokumen dan studi pustaka. Analisis dan interpretasi data dilakukan dengan mereduksi data, menyajikan data, menginterpretasi data dan menarik kesimpulan. Hasil dari penelitian ini adalah Politeknik Negeri Manado menjadi mitra dalam pelaksanaan CSR Bank Rakyat Indonesia dan juga menjadi pelaku kegiatan tanggungjawab sosial. Tanggungjawab sosial politeknik ditujukan bagi pihak intern, yaitu dosen dan mahasiswa serta pihak ekstern, yaitu masyarakat di luar kampus dan lingkungan. Kegiatan tanggungjawab sosial tersebut meliputi aspek sosial dan lingkungan yang dilakukan secara rutin setiap tahun, salah satunya melalui perwujudan Tridharma ketiga yaitu pengabdian kepada masyarakat, dan ada juga yang tidak rutin. Untuk kegiatan pengabdian kepada masyarakat dilakukan dalam bentuk fisik, non fisik, pelatihan dan bantuan sosial. Institusi pendidikan tinggi melaporkan aktivitas tanggungjawab sosialnya melalui laporan kegiatan, laporan penggunaan dana, laporan keuangan dan laporan akuntabilitas kinerja instansi pemerintah.
\end{abstract}


Kata kunci: tanggungjawab sosial institusi pendidikan tinggi, aktivitas tanggungjawab sosial, laporan aktivitas tanggungjawab sosial

\section{PENDAHULUAN}

Dewasa ini, Tanggungjawab Sosial Perusahaan menjadi isu yang hangat dibicarakan. Adanya pemanasan global, keretakan sosial dalam masyarakat, serta kerusakan lingkungan menjadi beberapa faktor yang mendorong perusahaan untuk bertanggungjawab sosial. Tanggungjawab sosial menjadi komitmen dari perusahaan untuk berperan serta dalam pembangunan berkelanjutan.

Dengan adanya UU No. 40 tahun 2007, perusahaan (Perseroan Terbatas) diwajibkan untuk melaksanakan Tanggungjawab Sosial dan Lingkungan. Bila dikaji lebih dalam, apakah tanggungjawab sosial hanya menjadi kewajiban dari perusahaan bisnis? Tentu saja tidak. Untuk melaksanakan pembangunan yang berkelanjutan dibutuhkan keterlibatan dari seluruh masyarakat Indonesia.

UU No. 32 tahun 2009 tentang Perlindungan dan Pengelolaan Lingkungan Hidup pasal 1 ayat 3, menjelaskan bahwa pembangunan berkelanjutan merupakan usaha yang terencana dan terarah untuk memenuhi kebutuhan dan meningkatkan kesejahteraan hidup manusia. Usaha yang terencana dan terarah tersebut perlu diupayakan oleh masyarakat sebagai unsur pelaksana pembangunan dengan memadukan aspek lingkungan hidup, sosial, dan ekonomi.

Terlaksananya pembangunan berkelanjutan menjadi tanggungjawab sosial dari seluruh masyarakat Indonesia. Tanggungjawab sosial ini tidak hanya berada di pundak pemerintah ataupun perusahaanperusahaan di Indonesia. Organisasi baik profit oriented, semi profit oriented dan social oriented adalah legal entity yang mempunyai tanggungjawab terhadap lingkungan sosial dan alam (Rowe et.al, 1992 dalam Subagyo dan Silalahi, 2014). Institusi pendidikan sebagai bagian dari masyarakat dan sebagai organisasi non profit juga memiliki tanggungjawab sosial untuk berkontribusi dalam pembangunan berkelanjutan.
Kontribusi dalam pembangunan berkelanjutan dari penyelenggaraan pendidikan tinggi tercermin dalam pasal 5 UndangUndang No. 12 tahun 2012 tentang Pendidikan Tinggi yang menyatakan tujuan diselenggarakannya pendidikan tinggi yaitu untuk mencerdaskan kehidupan bangsa dan kesejahteraan umat manusia. Pencapaian tujuan tersebut bila dilihat dalam konteks pembangunan berkelanjurtan dapat dikonkritkan dalam upaya-upaya yang dilakukan oleh institusi pendidikan tinggi melalui aktivitas tanggungjawab sosialnya. Konkretisasi upaya-upaya tersebut dengan mensinergikan pelaksanaan aktivitas institusi pendidikan tinggi dalam aspek sosial dan lingkungan..

Bagi perusahaan, kewajiban melaksanakan CSR melalui UU No. 40 tahun 2007 tetapi bentuk programnya belum ada standard. CSR dilaksanakan berdasarkan pemahaman dari masing-masing perusahaan atas CSR. Pelaksanaan tanggungjawab sosial dari institusi pendidikan tinggi juga belum secara khusus diatur oleh pemerintah. Belum ada program-program yang baku atau standar dalam pelaksanaan CSR sehingga CSR diterapkan secara berbedabeda. Karenanya, perusahaan maupun organisasi lainnya melaksanakan aktivitas CSR berdasarkan kebijakan intern mereka.

Subagyo dan Silalahi (2014) menyampaikan bahwa selama ini konsep CSR diterapkan pada perusahaan meskipun pada dasarnya setiap organisasi termasuk institusi pendidikan tinngi memiliki tanggungjawab sosial kepada masyarakat dan lingkungan. Tanggungjawab sosial tersebut dilaksanakan sebagai kegiatan pengabdian kepada masyarakat.

Kehadiran UU no. 40 tahun 2007 hanya mewajibkan perusahaan untuk bertanggungjawab sosial. Berdasarkan konsep organisasi sebagai legal entity berarti bahwa setiap organisasi apapun bentuknya memiliki tanggungjawab sosial termasuk 
institusi pendidikan tinggi. Kehadiran UU No. 32 tahun 2009 dan UU No. 12 tahun 2012 juga menyiratkan hal tersebut. Dalam penelitian Subagyo dan Silalahi (2014) ditemukan bahwa tanggungjawab sosial perguruan tinggi terletak pada Tridharma ketiga. Barried, Septarini dan Rahman (2012) juga mengemukakan adanya aktivitas Campus Social Responsibility pada tiga perguruan tinggi negeri di Surabaya yang bersinergi dengan Tridharma perguruan tinggi ketiga. Di sisi lain, peneliti melakukan survey awal di Politeknik Negeri Manado melalui wawancara dengan Kepala Unit Penjaminan Mutu. Menurut beliau, "CSR hampir tidak terdengar dikampus. Mungkin CSR diimplementasi dalam kegiatan pengabdian pada masyarakat atau juga pemberian bantuan kepada masyarakat yang mengalami bencana" (25 Februari 2016, via telepon, pukul 14.00). Dalam kenyataannya, CSR belum bergaung di institusi ini meskipun fenomena yang ada menunujukkan bahwa tanggungjawab sosial juga ada di dalam institusi pendidikan tinggi termasuk Politeknik Negeri Manado. Hal ini mendorong peneliti untuk menggali tanggungjawab sosial Politeknik Negeri Manado. Oleh sebab itu ada beberapa hal penting yang berkaitan dengan tanggungjawab sosial tersebut. Pertama, bagaimana konsep dan implementasi tanggungjawab sosial Politeknik Negeri Manado? Kedua, apakah implementasi tanggungjawab sosial Politeknik Negeri Manado hanya berbentuk pengabdian kepada masyarakat? Ketiga, bagaimana pelaporannya?

Dalam penelitian ini, peneliti hendak menggali, mendeskripsikan, dan menginterpretasi implementasi tanggungjawab sosial Politeknik Negeri Manado sebagai salah satu institusi penyelenggara pendidikan tinggi. Implementasi yang dimaksud tidak hanya berfokus pada aktivitas tanggungjawab sosial. Untuk memahami implementasi tersebut perlu diketahui konsep yang mendasari dan pengkomunikasian aktivitas tanggungjawab sosialnya melalui laporan yang digunakan oleh Politeknik Negeri Manado.

Hasil penelitian ini memberikan kontribusi bagi pengembangan ilmu pengetahuan khususnya di bidang Tanggungjawab Sosial Institusi Pendidikan Tinggi. Hasil penelitian ini juga membuka ruang yang baru bagi penelitian selanjutnya dengan melakukan penelitian pada institusi pendidikan yang berbeda sehingga dapat memperkaya khazanah ilmu pengetahuan di bidang Tanggungjawab Sosial (Social Responsibility) Institusi Pendidikan Tinggi. Hasil penelitian ini dapat memberi rekomendasi kepada institusi atas implementasi tanggungjawab sosial.

\section{TINJAUAN TEORETIS \\ Teori Stakeholder}

Menurut Freeman dan Evan (1988:39) stakeholders perusahaan merupakan pihakpihak yang memiliki klaim terhadap perusahaan. Pihak-pihak tersebut meliputi pemilik, pemasok, manajemen, pekerja, masyarakat lokal, konsumen dan pemerintah. Dapat juga dikatakan bahwa stakeholders perusahaan meliputi pihak-pihak yang berkepentingan dengan perusahaan baik yang dipengaruhi atau mempengaruhi secara langsung maupun tidak langsung oleh aktivitas bisnis perusahaan. Dalam kelompok stakeholders ini juga termasuk alam (Rumambi, 2014a). Setiap aktivitas yang dilakukan perusahaan mempengaruhi eksistensi alam. Sebaliknya, eksistensi alam juga mempengaruhi kelangsungan hidup perusahaan. Perusahaan hidup dan dihidupi oleh alam. Keberadaan alam dipengaruhi dan mempengaruhi perusahaan. Demikian juga dengan institusi pendidikan tinggi ataupun organisasi lainnya yang keberadaannya dipengaruhi dan mempengaruhi alam.

Jones (1995) dalam Solihin (2011) mengklasifikasi pemangku kepentingan dalam 2 kategori. Pertama, inside stakeholder, seperti pemegang saham, manajer dan karyawan. Mereka adalah orang-orang yang memiliki kepentingan dan tuntutan terhadap sumber 
daya perusahaan serta berada di dalam organisasi perusahaan. Kedua, outside stakeholder, seperti pelanggan, pemasok, pemerintah dan masyarakat. Mereka adalah pihak-pihak yang berada di luar perusahaan tetapi memiliki kepentingan terhadap perusahaan dan dipengaruhi oleh keputusan serta tindakan yang dilakukan oleh perusahaan.

\section{Tanggungjawab Sosial Perusahaan Tanggungjawab Sosial Perusahaan dan Pembangunan Berkelanjutan}

Dewasa ini, Tanggungjawab Sosial Perusahaan menjadi salah satu bentuk inovasi bagi hubungan perusahaan dengan masyarakat, pemerintah, konsumen, dan lingkungan. Pemerintah melalui UU no. 40 tahun 2007 tentang Perseroan Terbatas, mewajibkan Perseroan untuk berkomitmen melaksanakan Tanggungjawab Sosial Perusahaan. Komitmen tersebut diwujudkan melalui peran serta Perseroan dalam pembangunan ekonomi berkelanjutan. Komitmen tersebut ditujukan untuk meningkatkan kualitas kehidupan dan lingkungan bagi komunitas setempat, masyarakat umumnya bahkan bagi perseroan itu sendiri (Pasal 1).

Hal ini menunjukkan bahwa pelaksanaan Tanggungjawab Sosial Perusahaan tidak hanya berfokus kepada para shareholders melainkan juga kepada pihakpihak lain yang berkepentingan dengan perusahaan. Menurut Elkington (1997) dalam Rumambi (2014a), bisnis yang berkelanjutan perlu memperhatikan 3 aspek, yaitu aspek ekonomi, sosial dan lingkungan. Oleh sebab itu, Tanggungjawab Sosial Perusahaan difokuskan pada kesejahteraan masyarakat dan kelestarian lingkungan (Elkington, 1997, dalam Rumambi (2014b)

Menurut Comission of The European Communities (2001) dalam Green Paper 27, CSR memiliki dimensi internal dan eksternal. Tanggungjawab Sosial Perusahaan ditujukan kepada pekerja (dimensi internal) dan secara umum ditujukan kepada seluruh stakeholder termasuk mereka yang berada di luar perusahaan (dimensi eksternal).
Di sisi lain, Tanggungjawab Sosial Perusahaan dipahami sebagai klaim etis dari perusahaan dalam menjalankan aktivitas bisnisnya (Dahlia dan Siregar, 2008). Filho et al. (2010) mendefinisikan CSR melalui hubungan etika dan transparansi perusahaan dengan semua pemangku kepentingan. Hubungan etika dan transparansi perusahaan berkaitan dengan pembentukan tujuan perusahaan yang sesuai dengan pembangunan masyarakat berkelanjutan, melestarikan sumber daya lingkungan dan budaya untuk generasi mendatang, menghormati keragaman dan mempromosikan pengurangan masalah sosial. Sebagai klaim etis, keberadaan Tanggungjawab Sosial Perusahaan sebenarnya muncul dari adanya dampak negatif oleh aktivitas perusahaan, oleh sebab itu, untuk mengeliminir dampak negatif tersebut, perusahaan dalam aktivitasnya perlu mewujudkan pembangungan yang berkelanjutan.

Memahami Tanggungjawab Sosial Perusahaan tidak terlepas dari memahami konsep keberlanjutan (sustainability). Perusahaan yang mendukung pembangunan berkelanjutan adalah perusahaan yang bertanggungjawab sosial. Oleh sebab itu, aspek ekonomi, sosial dan lingkungan menjadi aspek dasar Tanggungjawab Sosial Perusahaan. Dengan aspek dasar tersebut, keberlanjutan dilihat sebagai proses pembangunan yang berprinsip memenuhi kebutuhan sekarang tanpa mengorbankan pemenuhan kebutuhan generasi masa depan. Hal ini ditegaskan dalam Brundtland (1987), "Humanity has the ability to make development sustainable to ensure that it meets the needs of the present without compromising the ability of future generations to meet their own needs."

Pertumbuhan nilai perusahaan/organisasi secara berkelanjutan tidak hanya ditentukan oleh perkembangan aspek ekonomi saja. Selain aspek ekonomi, aspek sosial dan aspek lingkungan hidup juga perlu diselaraskan. Hal ini sejalan dengan apa yang diamanatkan dalam konsep pembangunan berkelanjutan menurut UU 
no. 32 tahun 2009. Pembangunan berkelanjutan menjadi upaya sadar dan terencana dari seluruh rakyat Indonesia yang memadukan aspek lingkungan hidup, sosial, dan ekonomi dalam setiap aktivitasnya untuk menjamin keutuhan lingkungan hidup serta keselamatan, kemampuan, kesejahteraan, dan mutu hidup generasi masa kini dan generasi masa depan.

\section{Aktivitas Tanggungjawab Sosial Perusaha- an}

Kotler dan Lee (2011) mengkategorikan aktivitas Tanggungjawab Sosial Perusahaan dalam 6 aktivitas. Keenam aktivitas tersebut meliputi promosi kegiatan sosial (Cause promotions), pemasaran terkait kegiatan sosial (cause related marketing), pemasaran kemasyarakatan korporat (corporate societal marketing), kegiatan filantrofi perusahaan (corporate philanthropy), pekerja sosial kemasyarakatan secara sukarela (community volunteering), praktik bisnis yang memiliki tanggungjawab sosial (social responsible business practice).

Dalam aktivitas promosi kegiatan sosial perusahaan menyediakan dana atau sumber daya lainnya yang dimiliki perusahaan untuk meningkatkan kesadaran masyarakat terhadap suatu kegiatan sosial. Pada aktivitas pemasaran terkait kegiatan sosial, perusahaan menyumbangkan persentase tertentu dari penghasilannya untuk suatu kegiatan sosial berdasarkan besarnya penjualan produk. Di sisi lain, dalam aktivitas pemasaran kemasyarakatan korporat perusahaan mengembangkan dan melaksanakan kampanye untuk mengubah perilaku masyarakat dengan tujuan meningkatkan kesehatan dan keselamatan publik, menjaga kelestarian lingkungan hidup serta meningkatkan kesejahteraan masyarakat. Sebaliknya dalam kegiatan filantrofi perusahaan memberikan sumbangan langsung dalam bentuk derma untuk kalangan masyarakat tertentu. Pada aktivitas community volunteering perusahaan mendukung serta mendorong para karyawan serta pedagang eceran agar menyisihkan waktu secara sukarela untuk membantu organisasiorganisasi masyarakat lokal maupun masyarakat yang menjadi sasaran program. Selain itu, perusahaan perlu melaksanakan aktivitas bisnis melampaui aktivitas bisnis yang diwajibkan oleh hukum serta melaksanakan investasi yang mendukung kegiatan sosial dengan tujuan meningkatkan kesejahteraan komunitas dan memelihara lingkungan hidup. Jika dilihat dari berbagai aktivitas di atas, CSR menunjukkan cara bagi per- usahaan untuk berkontribusi pada kesejahteraan masyarakat. CSR juga memberikan kesempatan untuk menciptakan keunggulan kompetitif yang benar dan reputasi positif bagi dunia usaha (Smith, 2007; Porter dan Kramer, 2006). UU Nomor 40 Tahun pasal 74 ayat (2) menyebutkan bahwa, Tanggung Jawab Sosial dan Lingkungan merupakan kewajiban Perseroan yang dianggarkan dan diperhitungkan sebagai biaya perseroan yang pelaksanaannya dilakukan dengan memperhatikan kepatutan dan kewajaran. Kemudian Peraturan Pemerintah Nomor 47 Tahun 2012 pasal 5 menyebutkan antara lain perseroan yang menjalankan kegiatan usahanya di bidang dan/atau berkaitan dengan sumber daya alam, dalam menyusun dan menetapkan rencana kegiatan dan anggaran tanggungjawab sosial dan lingkungan harus memperhatikan kepatutan dan kewajaran. Realisasi anggaran untuk pelaksanaan tanggung jawab sosial dan lingkungan yang dilaksanakan oleh perseroan diperhitungkan sebagai biaya perseroan. Dalam pasal 6 disebutkan bahwa pelaksanaan tanggungjawab sosial dan lingkungan dimuat dalam laporan tahunan perseroan. Dari penjelasan tersebut dapat dikatakan bahwa biaya tanggungjawab sosial dan lingkungan perlu dianggarkan dan besarnya biaya tersebut ditentukan berdasarkan kebijakan perseroan dengan memperhatikan kepatutan dan kewajaran.

\section{Tanggungjawab Sosial Institusi Pendidik- an Tinggi}

Organisasi yang profit oriented maupun non profit oriented pada dasarnya mempunyai 
tanggungjawab sosial terhadap lingkungan sosial dan alam (Rowe et al., 1992 dalam Subagyo dan Silalahi, 2014). Subagyo dan Silalahi (2014) berpendapat bahwa perguruan tinggi mempunyai tanggungjawab sosial tidak hanya kepada masyarakat tetapi juga lingkungan. Tanggungjawab sosial tersebut terkandung dalam Tridharma Perguruan Tinggi ke-3, yaitu pengabdian pada msyarakat.

Untuk meningkatkan kualitas hidup masyarakat, organisasi maupun usaha bisnis perlu mempertimbangkan aspek etika, hukum, komersial dan harapan dari masyarakat umum. Tanggungjawab secara sosial, ekonomi dan lingkungan perlu menjadi pola pikir dan budaya dari organisasi ataupun usaha bisnis. Menurut Topal (2009), dampak sosial dari aktivitas universitas dapat dihitung dengan menggunakan pendekatan CSR.

Vallaeys (2013) mengidentifikasi tanggungjawab sosial universitas sebagai tanggungjawab atas aktivitas dan perilaku institusi yang dipengaruhi dan berdampak bagi masyarakat. Tanggungjawab tersebut menghendaki praktik-praktik manajemen yang mengeliminasi dampak negatif dan mendukung pembangunan yang berkelanjutan, oleh sebab itu, tanggungjawab sosial tersebut dilaksanakan seiring dengan kewajiban hukum dan melibatkan para stakeholders.

Dengan adanya keterlibatan para stakeholders, Muijen (2004) menyampaikan bahwa tanggungjawab sosial tercermin dalam visi, misi dan strategi organisasi. Oleh sebab itu, pelaksanaan CSR dalam organisasi tidak semata-mata dihasilkan dari strategi kepatuhan melainkan pelaksanaan CSR dalam hubungannya dengan strategi yang bertujuan untuk merangsang proses transformasi budaya organisasi. Kesuksesan CSR bergantung pada perilaku pelakunya yang mempengaruhi hubungan antara organisasi dan maysrakat.

Shawyun (2011) menekankan perlunya perilaku etis dalam semua aktivitas dan interaksi dengan seluruh stakeholders.
Karenanya, menurut Shawyun, tanggungjawab sosial universitas harus tercermin dalam visi dan misi mereka. Alvarez dan Lazano (2012) menyampaikan bahwa untuk menanggapi isu-isu keberlanjutan, lembaga pendidikan tinggi di seluruh dunia telah melibatkan kampus dan komunitas mereka dalam program-program keberlanjutan melalui konsep university social responsibility. Upaya tersebut telah menyebabkan perkembangan integritas dan etika nilai-nilai dalam organisasi dan hubungan mereka dengan para pemangku kepentingan.

Dari perspektif yang berbeda, Ahmad (2012) melakukan penelitian tentang kesadaran mahasiswa dan perilaku mereka dalam hal kontribusi terhadap praktik tanggung jawab sosial dalam konteks universitas Malaysia. Hasil penelitian menunjukkan bahwa sebagian responden menyadari kebutuhan untuk melestarikan lingkungan tetapi kurang dipraktekkan secara nyata. Oleh sebab itu, CSR perlu menjadi budaya dari organisasi (Muijen, 2004) dan tercermin dalam visi, misi dan strategi organisasi.

Menurut UU no. 12 tahun 2012 pasal 5, penyelengaraan pendidikan tinggi ditujukan untuk mencerdaskan kehidupan bangsa dan kesejahteraan umat manusia. Upaya institusi pendidikan tinggi untuk mencerdaskan kehidupan bangsa dan kesejahteraan umat manusia tidak terlepas dari upaya memadukan aspek lingkungan hidup dan sosial dalam kegiatan akademik (Subagyo dan Silalahi, 2014). Untuk menjaga kelestarian lingkungan, pelaksanaan tanggungjawab sosial institusi dimulai dari lingkungan terdekat, yaitu lingkungan kerja di institusi, lingkungan hidup di sekitar institusi kemudian lingkungan alam (Rumambi, 2016).

\section{Aktivitas Tanggungjawab Sosial Institusi Pendidikan Tinggi}

Baried, Septarini, dan Rahman (2012) dalam penelitiannya mengemukakan adanya aktivitas Campus Social Responsibility pada tiga perguruan tinggi negeri di 
Surabaya. Aktivitas tersebut merupakan program CSR yang disinergikan dengan penerapan Tridharma Perguruan Tinggi ketiga. Program tersebut dalam bentuk pemberdayaan Usaha Mikro Kecil dan Menengah. Mereka juga mengungkapkan bahwa adanya perguruan tinggi yang belum menjadikan CSR sebagai kebijakan.

Dalam penelitian Subagyo dan Silalahi (2014), Tanggungjawab Sosial Universitas Nusantara PGRI Kediri berfokus pada pihak internal kampus dan eksternal kampus. Tanggungjawab sosial tersebut diimplementasikan bagi internal kampus dalam bentuk program penyediaan sarana Hot Spot area 24 jam, food center, rest area, tempat parkir dengan CCTV, asrama mahasiswa poliklinik, sarana olah raga dan kesenian, serta beasiswa bagi mahasiswa berprestasi. Untuk pihak eksternal diadakan bakti sosial, zakat, khitan masal, ekspo basar murah maupun senam lansia.

Menurut Davis et al. (2003), untuk menyebarkan university social responsibility dilakukan gerakan keberlanjutan kampus. Gerakan keberlanjutan tersebut berbentuk upaya untuk mengurangi limbah dan melestarikan ekologi. Selain itu, kampus juga dapat berkontribusi terhadap stabilitas ekonomi dan menunjukkan tanggungjawab secara keseluruhan di kampus dan di masyarakat. Untuk itu dibutuhkan kerjasama dari segenap anggota dan administrator kampus yang menghubungkan inisiatif keberlanjutan kampus sebagai alat untuk memperluas hubungan profesional interdisipliner dan upaya kolaboratif.

Penelitian Dima et al. (2013) mengusulkan model tanggung jawab sosial dengan fokus pada enam dimensi yang meliputi, alumni oriented projects. interuniversity cooperation, university-high schools/ other institutions cooperation, communityoriented university-business management cooperation, community-oriented international cooperation, and socio-cultural and ecological projects.

Nejati et al. (2011), meneliti tanggungjawab sosial dari sepuluh universitas terkemuka di dunia. Hasil penelitiannya menemukan bahwa ke sepuluh universitas tersebut telah melaksanakan tanggung jawab sosial dalam area tata kelola organisasi berkaitan dengan akuntabilitas, transparansi, memberikan fakta dan angka. Selain itu, area hak asasi manusia dan praktik tenaga kerja. Praktik tenaga kerja meliputi imbalan kerja dan kompensasi, training dan pengembangan, menyediakan kerja yang sehat dan keseimbangan kehidupan. Lingkungan juga menjadi bagian dari tanggung jawab sosial. Tanggungjawab sosial terhadap lingkungan dilakukan dengan melestarikan lingkungan dan menawarkan program akademik khusus. Praktek operasi yang adil juga menjadi area dari tanggungjawab sosial yang mencakup keterlibatan bertanggung jawab dengan masyarakat dan mempromosikan tanggung jawab sosial. Area yang lain juga mencakup isu mahasiswa melalui pemberian informasi yang cukup bagi mahasiswa dan calon mahasiswa. Tanggungjawab sosial universitas juga berkaitan dengan keterlibatan dan pengembangan masyarakat dalam bentuk penyediaan hibah untuk proyek-proyek masyarakat serta menyediakan dana, mendukung untuk menghasilkan dan melestarikan perumahan yang terjangkau.

\section{Laporan Aktivitas Tanggungjawab Sosial}

Sebagai bagian dari kegiatan organisasi, Tanggungjawab Sosial Perusahaan merupakan salah satu bentuk informasi kualitatif dari akuntansi yang perlu dikomunikasikan kepada para stakeholders (Rumambi, 2014a). Informasi atas kegiatan tanggungjawab sosial tersebut digunakan oleh para stakeholders untuk menilai keberlanjutan organisasi di masa yang akan datang. Selain itu, informasi yang disampaikan kepada para stakeholders, membuat pihak-pihak yang berkepentingan dengan organisasi tersebut dapat mengetahui secara jelas kontribusi dari organisasi dalam kehidupan bermasyarakat. Menurut Shriberg (2002), agar informasi yang hendak disampaikan kepada berbagai pemangku kepentingan dapat 
dipahami maka mekanisme pelaporan yang jernih menjadi suatu kebutuhan bagi organisasi dalam keberlanjutannya.

Dalam konteks akuntansi, praktek pengkomunikasian aktivitas Tanggungjawab Sosial Perusahaan dilakukan melalui pengungkapan dalam suatu bentuk laporan. Seperti halnya aktivitas CSR diungkapkan dalam laporan keuangan, laporan tahunan ataupun laporan keberlanjutan (Rumambi, 2014a). Laporan tersebut digunakan sebagai alat manajemen dan alat komunikasi perusahaan untuk memberi informasi yang jelas dan transparan bagi para stakeholders. Bagi perusahaan di Indonesia, pengungkapan CSR diatur dalam pasal 66 C UU No. 40 tahun 2007 ataupun peraturan No. X.K.6 dari Kep-134/BL/2006 Badan Pengawas Pasar Modal dan Lembaga Keuangan..

Sebaliknya untuk institusi pendidikan tinggi, belum ada regulasi yang mengatur tentang tanggungjawab sosial institusi pendidikan tinggi. Bila dikaji dari konsep bahwa suatu organisasi baik profit maupun non profit memiliki tanggungjawab sosial maka pada dasarnya institusi pendidikan tinggi juga perlu untuk melaksanakan aktivitas tanggungjawab sosial. Implikasinya, dengan adanya aktivitas tanggungjawab sosial, maka institusi memerlukan wadah untuk mengkomunikasikan aktivitas tersebut dengan para stakeholders-nya.

\section{METODE PENELITIAN}

Penelitian kualitatif mendeskripsikan realitas Tanggungjawab Sosial Institusi Pendidikan Tinggi yang diteliti. Deskripsi ini menggunakan narasi yang diperoleh dari situasi yang alamiah berdasarkan apa yang dialami dan dipahami oleh partisipan/ sumber data. Dari deskripsi ini diperoleh pemahaman atas realitas tersebut.

Sukoharsono (2006:232) menyampaikan bahwa penelitian kualitatif memberikan holistic picture, variasi warna dan rasa. Oleh sebab itu diperlukan proses pelaporan yang detail. Kesemuanya ini dimaksudkan bahwa memecahkan persoalan tidaklah dengan serpihan atau mereduksi realitas, tetapi keutuhan gambar dan warna.

Taylor et al. (2016) menjelaskan penelitian kualitatif sebagai suatu penelitian yang dilakukan melalui wawancara mendalam dan menghasilkan data deskriptif. Data deskriptif tersebut berupa ucapan seseorang dan perilaku orang-orang yang diamati.

Politeknik Negeri Manado digunakan sebagai situs penelitian dalam penelitian ini untuk memperoleh data dan informasi yang diperlukan dalam mendeskripsikan dan menginterpretasi implementasi tanggungjawab sosial. Situs penelitian terletak di Kampus Politeknik Negeri Manado desa Buha Manado. Penelitian ini menggunakan data primer dan data sekunder. Data primer bersumber dari hasil wawancara dengan informan yang digunakan dalam penelitian ini. Informan tersebut meliputi Direktur Politeknik Negeri Manado, Wakil Direktur Bidang Akademik, pegawai, kepala pusat penjaminan mutu serta kepala bagian perencanaan kerjasama dan hubungan masyarakat yang pada periode sebelumnya menjabat sebagai kepala bagian keuangan).

Data sekunder yang digunakan bersumber dari laporan kegiatan pengabdian kepada msayarakat Politeknik Negeri Manado, hasil observasi kegiatan, laporan keuangan Politeknik Negeri Manado, laporan akuntabilitas kinerja instansi pemerintah Politeknik Negeri Manado, peraturan perundang-undangan serta berbagai buku referensi dan jurnal yang berkaitan dengan tanggungjawab sosial.

Dalam penelitian ini, peneliti melakukan wawancara dengan berbagai informan, observasi serta studi kepustakaan dan studi dokumen. Wawancara dilakukan secara semi terstruktur. Peneliti telah mempersiapkan terlebih dahulu materi apa saja yang akan ditanyakan dan perkembangan wawancara selanjutnya bergantung dari jawaban informan. Observasi dilakukan melalui keikutsertaan/kehadiran peneliti sebagai seorang staf dosen yang terlibat dalam berbagai aktivitas Politeknik Negeri 
Manado. Studi kepustakaan dilakukan dengan mempelajari berbagai buku referensi dan jurnal yang berkaitan dengan tanggungjawab sosial. Studi dokumen dilakukan peneliti dengan melihat laporan kegiatan, laporan akuntabilitas kinerja instansi pemerintah (LAKIP) 2015 Politeknik Negeri
Manado dan laporan keuangan Politeknik Negeri Manado.

Teknik analisis data dilakukan secara kualitatif dengan mengacu pada analisis data Miles dan Huberman (1992). Adapun tahapan penelitian yang dilakukan sebagai berikut:

Tahap 1

Tahap 2

Tahap 3

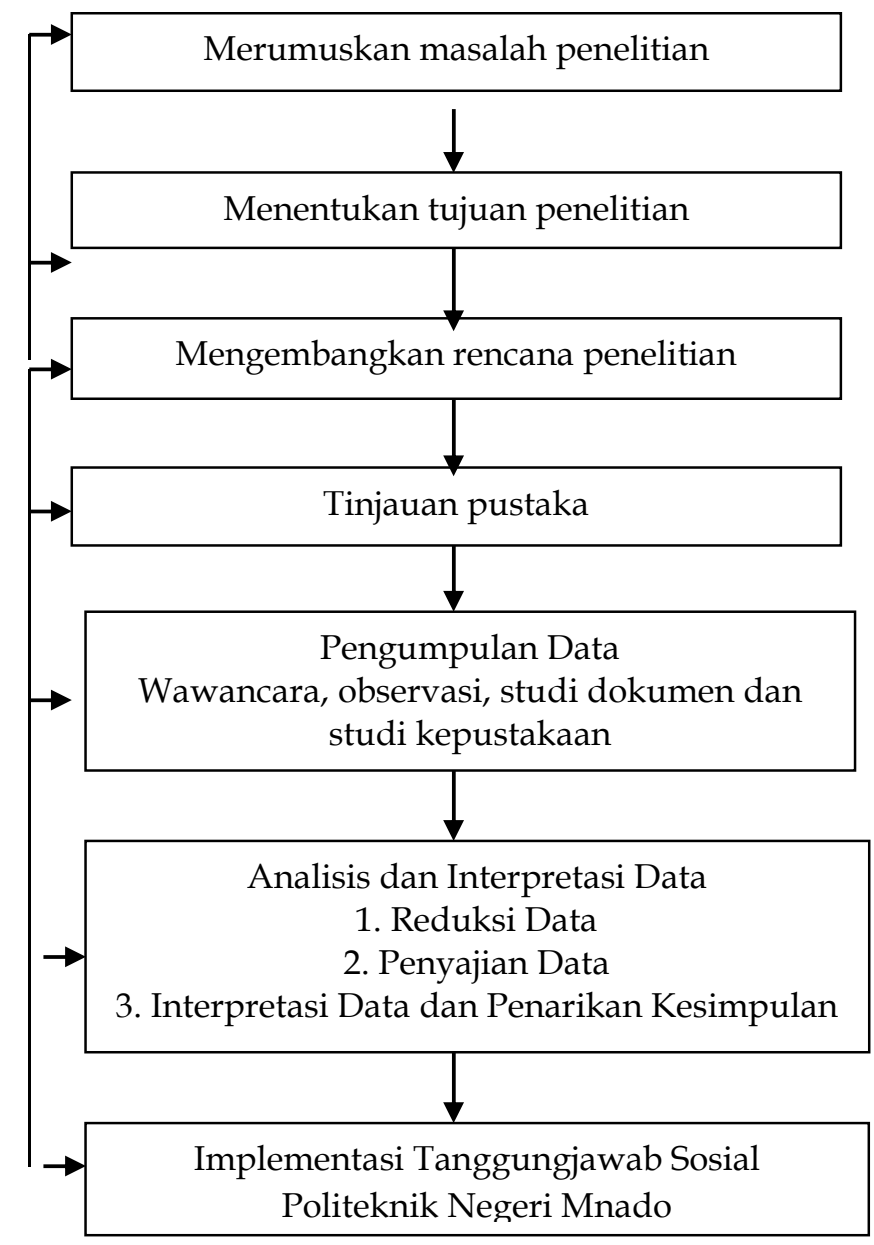

\section{Gambar 1 \\ Tahapan Penelitian}

Tahap 1 merupakan proses untuk menentukan masalah penelitian, menetapkan tujuan penelitian dan mengembangkan rencana penelitian. Untuk melaksanakan proses pada tahap 1 dilakukan studi tinjauan pustaka atas UU No. 32 tahun 2009 yang menegaskan mengenai pembangunan berkelanjutan dan UU No. 12 tahun 2012 tentang Pendidikan Tinggi yang menjadi dasar pelaksanaan tanggungjawab sosial.
Selain itu, peneliti juga mengkaji beberapa penelitian dan teori yang relevan dengan penelitian seperti konsep organisasi dari Rowe et.al yang menyatakan organisasi non profitpun memiliki tanggungjawab sosial. Peneliti juga melakukan wawancara awal dengan beberapa staf dosen untuk mengetahui pemahaman mereka atas tanggungjawab sosial. Bertolak dari hal-hal tersebut, maka peneliti tertarik untuk menggali 
implementasi dari tanggungjawab sosial Politeknik Negeri Manado dalam suatu desain penelitian kualitatif.

Tahap 2 merupakan proses untuk menguraikan berbagai teori yang diperoleh dari berbagai acuan untuk dijadikan landasan teori dalam pelaksanaan penelitian. Teori-teori yang dikumpulkan berfokus pada topik penelitian, yaitu tanggungjawab sosial. Pada tahap 2 ini juga peneliti menentukan teknik pengumpulan data yang akan digunakan. Peneliti melakukan penelitian lapangan untuk mengumpulkan data tentang implementasi tanggungjawab sosial pada Politeknik Negeri Manado. Teknik pengumpulan data yang digunakan adalah wawancara, observasi, studi dokumen dan studi kepustakaan.

Tahap 3 merupakan proses untuk mengolah data yang dikumpulkan pada tahap 2. Analisis dan interpretasi data menggunakan tahap analisis data dari Miles dan Huberman (1992) yang terdiri dari 3 tahap, yaitu reduksi data, penyajian data dan penarikan kesimpulan. Data yang dikumpulkan direduksi sesuai dengan topik penelitian. Hasil reduksi tersebut disajikan berdasarkan tema-tema yang terkait topik penelitian seperti konsep tanggungjawab sosial, aktivitas tanggungjawab sosial, dan pelaporan aktivitas tanggungjawab sosial. Data tanggungjawab sosial yang dikumpulkan, dianalisis dan disimpulkan merupakan data tanggungjawab sosial dari Politeknik Negeri Manado. Interpretasi dan penarikan kesimpulan yang dilakukan merupakan implementasi tanggungjawab sosial Politeknik Negeri Manado.

\section{ANALISIS DAN PEMBAHASAN}

\section{Konsep Tanggungjawab Sosial Politeknik} Negeri Manado

Sebagai salah satu penyelenggara pendidikan tinggi, Politeknik Negeri Manado dalam segala aktivitasnya berpusat pada Tridharma Perguruan Tinggi atau disebut Tridharma. Menurut UU No. 12 tahun 2012 tentang pendidikan tinggi, Tridharma merupakan kewajiban perguruan tinggi untuk menyelenggarakan pendidikan, penelitian dan pengabdian kepada masyarakat.

Pendidikan merupakan upaya-upaya yang dilakukan secara terencana untuk mewujudkan suasana belajar dan proses pembelajaran sehingga peserta didik dapat secara aktif mengembangkan potensi diri demi dirinya sendiri, masyarakat, bangsa dan negara. Penelitian merupakan kegiatan untuk memperoleh pemahaman dan pengujian ilmu pengetahuan dan teknologi. Untuk itu suatu penelitian dilaksanakan secara sistematis berdasarkan kaidah dan metode ilmiah. Pengabdian kepada masyarakat merupakan aktivitas yang dilaksanakan oleh sivitas akademika dengan menggunakan ilmu pengetahuan dan teknologi demi mewujudkan kesejahteraan masyarakat dan mencerdaskan kehidupan bangsa. Sesuai Peraturan Menteri Riset, Teknologi dan Pendidikan Tinggi no. 44 tahun 2015 pasal 57, kegiatan pengabdian pada masyarakat dapat berupa pelayanan kepada masyarakat, penerapan ilmu pengetahuan dan teknologi sesuai bidang keahliannya, peningkatan kapasitas masyarakat atau pemberdayaan masyarakat. Sebagai institusi pendidikan tinggi, Politeknik Negeri Manado memiliki kewajiban untuk melaksanakan Tridharma. Di sisi lain, Politeknik Negeri Manado sebagai sebuah organisasi (legal entity) dan bagian dari masyarakat Indonesia mempunyai tanggungjawab sosial. Menurut Direktur Politeknik Negeri Manado,

CSR tidak hanya dilaksanakan oleh perusahaan bisnis saja, perguruan tinggipun memiliki tanggungjawab sosial. CSR untuk perguruan tinggi belum diwajibkan dan tidak di undang-undangkan. Selama ini CSR belum dikenal dalam lingkungan kampus walaupun pada kenyataannya politeknik telah melakukan aktivitas tanggungjawab sosialnya.

Dari penyampaian Bapak Direktur tersebut, perguruan tinggi juga memiliki tanggungjawab sosial dan melaksanakan CSR walaupun belum diatur dalam UndangUndang. 
Tanggungjawab sosial tersebut ada karena keterlibatan dari para stakeholdersnya. Stakeholders merupakan pihak-pihak yang mempengaruhi dan dipengaruhi oleh aktivitas dari Politeknik. Keberadaan Politeknik tidak terlepas dari peranan para stakeholders-nya. Sebagai bagian dari masyarakat, Politeknik mengemban tugas sesuai UU no. 12 tahun 2012 untuk turut serta mencerdaskan masyarakat melalui kegiatan pendidikan, penelitian dan pengabdian kepada masyarakat. Dapat dikatakan, bertolak dari teori stakeholder Freeman dan Evan (1989), pemangku kepentingan dari politeknik merupakan pihak-pihak yang berkepentingan secara langsung maupun tidak langsung dengan penyelenggaraan pendidikan tinggi melalui pelaksanaan Tridharmanya.

Sejalan dengan teori stakeholder (Commision of The European Communities, 2001), Direktur Politeknik Negeri Manado mengatakan bahwa pemangku kepentingan dari institusi pendidikan tinggi meliputi stakeholder intern dan ekstern. Hal ini secara jelas disampaikan oleh Bapak Direktur, "Stakeholder intern adalah dosen dan mahasiswa sebagai sivitas akademika serta pegawai. Stakeholder ekstern adalah masyarakat di luar politeknik."

Dalam pelaksanaan tanggungjawab sosial, politeknik perlu menetapkan kriteria untuk menentukan aktivitas apa saja yang menjadi aktivitas tanggungjawab sosial. Hal ini perlu karena mengingat politeknik sebagai sebuah lembaga pemerintah tentu saja pemahaman akan aktivitas tanggungjawab sosial berbeda dengan yang ada di perusahaan. Segala yang dilakukan politeknik berkaitan dengan regulasi pemerintah. Oleh sebab itu perlu adanya kriteria yang dapat digunakan oleh politeknik dalam menentukan aktivitas tanggungjawab sosialnya.

Adapun kriteria yang digunakan untuk menggolongkan suatu aktivitas sebagai aktivitas tanggungjawab sosial, menurut Direktur,
Suatu aktivitas yang dilaksanakan oleh Politeknik Negeri Manado untuk memenuhi hak dasar dari dosen atau mahasiswa sebagai sivitas akademika (sesuai dengan yang distandarkan) maka aktivitas tersebut tidak dapat digolongkan sebagai aktivitas tanggungjawab sosial. Sebaliknya, kegiatan pengabdian kepada masyarakat dipahami sebagai aktivitas tanggungjawab sosial kepada masyarakat karena aktivitas tersebut mencerminkan kontribusi/kepedulian politeknik dalam kehidupan sosial bermasyarakat.

Penyampaian Bapak Direktur tersebut menunjukkan bahwa tanggungjawab sosial ada yang dilaksanakan untuk pihak intern (sivitas akademika) dan pihak ekstern (masyarakat) politeknik. Bagi pihak intern politeknik, suatu aktivitas tanggungjawab sosial adalah ketika aktivitas tersebut dilaksanakan tidak dalam rangka pemenuhan hak dasar sivitas akademika. Bagi pihak ekstern, kegiatan pengabdian kepada masyarakat dipandang sebagai kegiatan tanggungjawab sosial karena dalam kegiatan tersebut Politeknik Negeri Manado berkontribusi terhadap kehidupan sosial bermasyarakat.

Hal senada juga disampaikan oleh Wakil Direktur bidang akademik bahwa kegiatan tanggungjawab sosial ada di Politeknik Negeri Manado dan berbentuk kegiatan pengabdian kepada masyarakat. Menurut salah satu pegawai bagian penelitian dan pengabdian kepada masyarakat, sebelum melaksanakan kegiatan tersebut, dibentuk tim yang akan melakukan survey untuk menganalisis situasi dan kondisi dari masyarakat di mana kegiatan pengabdian akan dilaksanakan. Hal ini dapat dilihat dari analisis situasi yang dilakukan oleh tim pengabdian kepada masyarakat. Analisis tersebut dilakukan untuk menentukan lokasi kegiatan dan menggali kondisi sosial serta kehidupan masyarakat dari desa yang akan dipilih. 
Hasil analisis tersebut memberikan gambaran yang jelas bagi tim pengabdian mengenai kontribusi apa saja yang dapat diberikan oleh politeknik guna meningkatkan kesejahteraan hidup mereka (Laporan Kegiatan Pengabdian kepada Masyarakat, 2014 dan 2015).

Menurut Kepala Bagian Perencanaan Kerjasama dan Hubungan Masyarakat,

Tanggungjawab sosial Politeknik

Negeri Manado dapat dipahami dari 2 sisi, yaitu politeknik sebagai mitra dalam pelaksanaan CSR dari perusahaan dan sebagai pelaku kegiatan tanggungjawab sosial. Sebagai mitra berarti politeknik menjadi bagian dari program CSR perusahaan. Sebagai pelaku maka politeknik melaksanakan berbagai aktivitas tanggungjawab sosial dalam lingkup Tridharmanya. Dalam lingkup tersebut, tanggungjawab sosial Politeknik Negeri Mana do ditujukan untuk pihak intern maupun pihak ekstern sebagai stakeholders politeknik. Pihak intern yang dimaksud adalah sivitas akademika yaitu dosen dan mahasiswa sedangkan pihak ekstern adalah masyarakat di luar kampus. Selain itu Politeknik Negeri Manado juga melakukan tanggungjawab sosial yang berkaitan dengan lingkungan.

Berdasarkan penjelasan tersebut diatas, dalam aktivitas tanggungjawab sosialnya, politeknik menjadi mitra perusahaan yaitu bagian dari program CSR perusahaan dan politeknik sendiri juga menjadi pelaku aktivitas. Aktivitas tanggungjawab sosial politeknik tidak hanya untuk pihak intern dan ekstern politeknik tetapi juga berkaitan dengan lingkungan. Setiap aktivitas yang dilakukan politeknik mempengaruhi alam. Hal ini sejalan dengan apa yang disampaikan oleh Rumambi (2014a) dan Subagyo dan Silalahi (2014) bahwa organisasi ataupun perusahaan perlu untuk melaksanakan tanggungjawab sosial terhadap lingkungan.

Bila dilihat dalam konteks Tridharma peguruan tinggi, tanggungjawab sosial ke- pada masyarakat di luar kampus diwujudkan melalui pelaksanaan Tridharma ketiga yaitu pengabdian kepada masyarakat. Direktur Politeknik Negeri Manado menyampaikan bahwa pelaksanaan Tridharma sebagai bagian dari kegiatan akademik juga bagian dari kepedulian sosial politeknik terhadap masyarakat. Direktur dengan tegas menyampaikan bahwa kehadiran politeknik untuk membantu dan memberikan alternatif solusi terhadap persoalan-persoalan yang ada dimasyarakat.

Sebagai bagian dari kegiatan akademik, tanggungjawab sosial yang dilaksanakan melalui kegiatan pengabdian kepada masyarakat dalam bentuk pelayanan kepada masyarakat, pemberdayaan masyarakat serta transfer ilmu dan praktek ketrampilan. Kegiatan pengabdian pada masyarakat dikoordinir oleh Unit Penelitian dan Pengabdian kepada Masyarakat. Setiap tahun dibentuk panitia khusus dari keenam jurusan yang ada. Pelaksanaan kegiatan tersebut sesuai dengan bidang keahlian dari masingmasing jurusan. Selain itu untuk mempererat kedekatan dan kepedulian sosial, Politeknik Negeri Manado terlibat dalam bakti sosial dengan masyarakat yang mengalami bencana.

\section{Aktivitas Tanggungjawab Sosial Poli- teknik Negeri Manado}

Konsep melahirkan aktivitas. Aktivitas tanggungjawab sosial yang dilaksanakan oleh Politeknik Negeri Manado ditujukan bagi dosen, mahasiswa, masyarakat dan lingkungan alam. Selain menjadi pelaku tanggungjawab sosial, Politeknik Negeri Manado menjalin kerjasama dengan PT. Bank Rakyat Indonesia (Persero) Tbk (Bank BRI). Kepala Bagian Perencanaan Kerjasama dan Hubungan Masyarakat menjelaskan,

Politeknik menjalin kerjasama dengan Bank BRI. Kerjasama tersebut dalam bentuk pembayaran gaji karyawan melalui Bank BRI. Di tahun 2016, PT. Bank Rakyat Indonesia memberikan bantuan Corporate Society Responsibility (CSR) Peduli Pendidikan dalam 
bentuk satu unit minibus senilai Rp. 355.500.000,-. Bantuan ini diberikan untuk menunjang kegiatan akademik Politeknik Negeri Manado. Dengan terlibat dalam program CSR Peduli Pendidikan Bank BRI, maka Politeknik menjadi mitra dalam pelaksanaan CSR. Politeknik juga mengikuti program penugasan ADB (Asean Development Banking). Politeknik ditugaskan untuk menjadi pusat unggulan teknologi pengolahan kayu kelapa dan produk turunannya. Diharapkan politeknik bisa menghasilkan produk yang membantu petani kelapa. Selain itu politeknik dapat menciptakan teknologi baru untuk meningkatkan produktivitas dan kesejahteraan petani kelapa.

Dari penjelasan Bapak Kepala Bagian, Politeknik Negeri Manado dalam aktivitas tanggungjawab sosialnya menjadi mitra dari Bank BRI dan Asean Development Banking. Sebagai pelaku CSR, Politeknik Negeri Mana do melaksanakan berbagai kegiatan tanggungjawab sosial meliputi kegiatan yang ditujukan untuk pihak intern dan ekstern politeknik serta lingkungan. Sejalan dengan Politeknik Negeri Manado, tiga perguruan tinggi negeri di Surabaya mensinergikan program CSR mereka dalam memberdayakan UMKM melalui penerapan Tridharma ketiga (Baried, Septarini dan Rahman, 2012). Universitas Nusantara PGRI Kediri mengimplementasikan tanggungjawab sosial mereka dalam penyediaan berbagai sarana untuk kebutuhan mahasiswa, pemberian beasiswa bagi mahasiswa dan berbagai kegiatan sosial untuk masyarakat. Dima et al. (2013) dan Nejati et al. (2011) juga memberikan area yang berbeda dalam pelaksanaan tanggungjawab sosial yang lebih berfokus pada pengelolaan manajemen. Hal ini menunjukkan bahwa aktivitas tanggungjawab sosial institusi pendidikan tinggi dilaksanakan berdasarkan kebijakan intern institusi.

Aktivitas tanggungjawab sosial untuk pihak intern meliputi kegiatan rutin dan kegiatan tidak rutin. Kegiatan rutin meliputi pemberian beasiswa akademik bagi mahasiswa berprestasi, beasiswa bidik misi bagi mahasiswa dari keluarga kurang mampu. Selain itu, politeknik juga memberikan bantuan penyelesaian studi bagi dosen S2 dan S3. Untuk kegiatan tidak rutin seperti pelatihan dan tes bahasa Inggris bagi mahasiswa. Dalam menghadapi era Masyarakat Ekonomi Asean, lulusan mahasiswa Politeknik diperhadapkan pada persaingan kerja yang lebih ketat. Untuk itu Politeknik Negeri Manado mempersiapkan mahasiswanya melalui pelatihan bahasa Inggris dengan bekerjasama dengan International Test Centre Jakarta.

Selain itu politeknik juga memberikan bantuan dana bagi dosen untuk mengikuti pelatihan dalam bidang keahlian tertentu. Sebagai tenaga pendidik, dosen harus selalu dapat mengembangkan ilmu pengetahuan dan kompetensi yang dimilikinya melalui kegiatan pelatihan. Bentuk kegiatan tidak rutin lainnya, yaitu memberikan bantuan sertifikasi kompetensi bagi mahasiswa. Dalam menghadapi tuntutan dari dunia industri dimana mereka mensyaratkan calon tenaga kerja harus memiliki sertifikat kompetensi, maka politeknik memberikan bantuan uji kompetensi dengan dana ditanggung oleh politeknik kepada beberapa mahasiswa yang memenuhi kriteria yang disyaratkan

Untuk pihak ekstern, aktivitas tanggungjawab sosial meliputi kegiatan rutin dan tidak rutin. Seperti yang disampaikan oleh Kepala Bagian Perencanaan Kerjasama dan Hubungan Masyarakat bahwa kegiatan rutin ini terdiri dari 3 kegiatan. Kegiatan rutin tersebut dilakukan dalam bentuk kegiatan pengabdian kepada masyarakat, memberikan kesempatan kerja bagi masyarakat di sekitar kampus serta menyediakan website Polimdo sebagai sarana untuk berkomunikasi dengan para stakeholders.

Pertama, kegiatan pengabdian kepada masyarakat. Kegiatan pengabdian kepada masyarakat meliputi program fisik, program 
non fisik, program pelatihan dan bantuan sosial. Program fisik dilakukan dalam bentuk bedah rumah, pemasangan instalasi listrik, lantainisasi dan demo masak serta demo penyiapan hidangan. Bedah rumah dilakukan untuk rumah yang sudah tidak layak ditinggali. Kegiatan pemasangan instalasi listrik dilakukan sebagai bentuk pelatihan mengenai instalasi listrik yang baik dan perbaikan serta pemasangan instalasi listrik pada beberapa rumah penduduk. Untuk lantainisasi, kegiatan ini dilakukan pada beberapa rumah penduduk demi meningkatkan kehidupa dan taraf hidup masyarakat. Dalam kegiatan demo masak dan penyiapan hidangan, masyarakat diajarkan berbagai macam masakan yang higienis dan sekaligus masyarakat diajarkan tata cara penyiapan hidangan (Laporan Kegiatan Pengabdian kepada Masyarakat, 2014 dan 2015).

Pada program non fisik, sebagaimana disampaikan dalam laporan kegiatan pengabdian kepada masyarakat tahun 2014 dan 2015, tim pengabdian kepada masyarakat melakukan sosialisasi dan penyuluhan perpajakan. Sosialisasi dan penyuluhan ini dilakukan untuk memberi pemahaman kepada masyarakat mengenai tata cara perhitungan pajak bumi dan bangunan, pajak penghasilan dan pelatihan pengisian formulir pajak sederhana. Selain itu, tim pengabdian juga melakukan penyuluhan higienitas dan sanitasi makanan. Masyarakat diberikan pemahaman mengenai higienitas dan sanitasi makanan. Melalui penyuluhan ini masyarakat diajarkan cara menjaga kebersihan makanan mulai dari penyiapan bahan, penyimpanan bahan, pengelolaan dan penyajiannya sehingga memenuhi standar higienitas. Kegiatan lainnya dilakukan dalam bentuk sosialisasi dan penyuluhan administrasi sederhana. Sosialisasi dan penyuluhan ini mengangkat topik mengenai penghapusan kekerasan dalam rumah tangga. Masyarakat dibekali mengenai tata penataan administrasi dan penanganan surat menyurat pasca terjadinya kekerasan sehingga perempuan dan anak-anak mendapatkan perlindungan atas hak-haknya. Selain itu tim pengabdian juga melakukan sosialisasi dan penyuluhan bangunan tahan gempa. Sosialisasi dan penyuluhan ini dimaksudkan untuk memberikan bimbingan dan bantuan teknik mengenai konstruksi bangunan tahan gempa yang paling cocok untuk diterapkan.

Kegiatan pengabdian kepada masyarakat lainnya dilakukan dalam bentuk program pelatihan (Laporan Kegiatan Pengabdian kepada Masyarakat, 2014 dan 2015). Program pelatihan yang dimaksud dilakukan melalui pelatihan bangunan tahan gempa. Dalam pelatihan ini masyarakat dilatih mengenai teknik membangun bangunan tahan gempa. Selain itu, masyarakat dilatih untuk membuat laporan pajak sederhana dan menghitung pembayaran pajak penghasilan melalui pelatihan pembuatan laporan pajak sederhana. Masyarakat juga diberi pelatihan tata boga untuk membuat nakanan sehat dari bahan-bahan yang ada di desa tersebut. Pelatihan yang lain yang dilakukan seperti pelatihan dasar pengelasan. Pelatihan ini bertujuan untuk melatih dan membimbing masyarakat mengenai teknik dasar pengelasan yang baik dan benar serta diikuti dengan praktek kerjanya. Tim pengabdian juga melakukan pelatihan dasar instalasi jaringan listrik untuk perumahan. Maksud pemberian pelatihan ini, yaitu masyarakat dilatih dan dibimbing mengenai teknik dasar pemasangan instalasi listrik yang disyaratkan oleh PLN. Masyarakat juga mengadakan praktek pemasangan instalasi di rumahrumah.

Selain melakukan kegiatan sosialisasi, penyuluhan, dan pelatihan, tim pengabdian juga melaksanakan program bantuan sosial. Dalam program ini, masyarakat diberi bantuan perlengkapan dan peralatan sekolah serta bantuan buku dan perlengkapan tulis menulis. Program bantuan sosial ini merupakan kegiatan filantrofi Politeknik Negeri Manado. Seperti yang disampaikan oleh Kotler dan Lee (2011), kegiatan filantrofi merupakan salah satu bentuk aktivitas CSR. 
Melalui kegiatan filantrofi ini, politeknik memberikan sumbangan langsung bagi masyarakat yang membutuhkan.

Kedua, Politeknik Negeri Manado membuka lapangan kerja bagi masyarakat sekitar kampus. Politeknik merekrut sebagian besar pramubakti dan sekuriti dari masyarakat lingkungan kampus. Hal ini dilakukan agar kehadiran Politeknik Negeri Manado dapat bermanfaat bagi masyarakat sekitar dan membantu mensejahterakan kehidupan masyarakat.

Ketiga, politeknik menyiapkan website Polimdo (www.polimdo.ac.id). Keberadaan website polimdo untuk memudahkan para stakeholders dalam mengakses informasi mengenai politeknik. Penyampaian informasi tersebut dilakukan secara rutin pada website polimdo.

Selain itu, kegiatan tidak rutin yang dilaksanakan seperti jasa konsultasi ISO bagi lembaga pendidikan tingkat SMA, SMK maupun politeknik. Kegiatan tidak rutin lainnya yaitu dengan mengadakan bakti sosial bersama Pemerintah Kota Manado untuk membantu daerah-daerah yang terkena bencana banjir pada tahun 2014. Untuk menjaga kelestarian lingkungan dilakukan penanaman pohon melalui keikutsertaan dalam gerakan penanaman sejuta pohon demi mengantisipasi pemanasan global. Wakil Direktur bidang akademik juga menjelaskan kegiatan tidak rutin lainnya yang dilakukan oleh politeknik seperti community service dan community development. Community service dilakukan oleh mahasiswa dengan mengajar bahasa Inggris kepada anak-anak SD, sopir-sopir taksi. Community development melalui program bina desa wisata dan program mahasiswa wirausaha.

Dari berbagai aktivitas tanggungjawab sosial Politeknik Negeri Manado baik sebagai mitra CSR maupun pelaku CSR dapat dikatakan bahwa aspek dasar tanggungjawab sosial Politeknik Negeri Manado meliputi aspek sosial dan lingkungan. Aspek sosial menunjukkan keterlibatan Politeknik
Negeri Manado dalam mensejahterakan masyarakat di dalam dan di luar politeknik. Aspek lingkungan menunjukkan peran serta politeknik dalam menjaga kelestarian lingkungan. Seperti yang disampaikan oleh Alvarez dan Lazano (2012) dan Davis et al. (2003), university social responsibility dilakukan oleh lembaga/institusi untuk menanggapi isu-isu keberlanjutan. Dengan adanya aspek sosial dan aspek lingkungan sebagai aspek dasar tanggungjawab sosial Politeknik Negeri Manado berarti politeknik ikut serta dalam mewujudkan pembangunan berkelanjutan,.

\section{Laporan Aktivitas Tanggungjawab Sosial Politeknik Negeri Manado}

Tanggungjawab sosial sebagai salah satu aktivitas dari organisasi ataupun institusi perlu untuk dikomunikasikan dengan para stakeholders-nya. Rumambi (2014a) menyampaikan bahwa informasi yang berkaitan dengan tanggungjawab sosial merupakan informasi kualitatif dari akuntansi. Informasi kualitatif tersebut berkaitan dengan bentuk kegiatan, pihakpihak yang terlibat dan hasil yang dicapai. Di sisi lain, aktivitas tanggungjawab sosial secara kuantitatif menimbulkan konsekuensi penggunaan dana.

Sebagai institusi yang aktivitas dan pendanaannya diatur melalui undangundang ataupun peraturan-peraturan yang dikeluarkan pemerintah, maka dana yang dibutuhkan sudah harus dianggarkan terlebih dahulu. Kepala Bagian Perencanaan Kerjasama dan Hubungan Masyarakat menjelaskan, "dana pengabdian kepada masyarakat Politeknik Negeri Manado dianggarkan sebanyak Rp. 150.000.000,/tahun untuk tahun 2015 dan 2016 sedangkan tahun 2017 meningkat menjadi Rp. 270.000.000,-. Adanya penganggaran tersebut menjadi dasar untuk pelaksanaan kegiatan." Ketika suatu kegiatan sudah selesai dilaksanakan maka informasi dan pendanaan kegiatan tersebut perlu dikomunikasikan ke berbagai pihak melalui 
Laporan Keuangan dan LAKIP Politeknik Negeri Manado.

Secara kualitatif, aktivitas tanggungjawab sosial dikomunikasikan kepada para stakeholders melalui Laporan Kegiatan Pengabdian kepada Masayarakat. Informasi tersebut secara umum berkaitan dengan jenis kegiatan yang dilaksanakan, waktu dan tempat, siapa yang terlibat (Laporan Kegiatan Pengabdian kepada Masyarakat, 2014 dan 2015). Adapun besarnya dana yang terserap dalam kegiatan itu dilaporkan dan dipertanggungjawabkan oleh panitia pengabdian kepada masyarakat melalui laporan penggunaan dana. Laporan ini merupakan bentuk pertanggungjawaban dari aktivitas yang sudah dilaksanakan.

Adapun dana yang digunakan untuk kegiatan tanggungjawab sosial, tidak hanya dilaporkan tersendiri dalam laporan penggunaan dana tetapi menjadi bagian dari laporan keuangan politeknik. Laporan kegiatan dan laporan penggunaan dana menjadi laporan pendukung dari laporan keuangan (dalam laporan realisasi anggaran/LRA) dan laporan akuntabilitas kinerja instansi pemerintah. Jumlah dana yang dimanfaatkan untuk aktivitas tanggungjawab sosial dalam laporan realisasi anggaran dicatat pada pos belanja barang dan belanja bantuan sosial (Laporan Keuangan dan LAKIP, 2015). Dapat dikatakan, laporan kegiatan, laporan penggunaan dana, laporan keuangan dan laporan akuntabilitas kinerja instansi pemerintah menjadi alat komunikasi dan sarana pertanggungjawaban tanggungjawab sosial Politeknik Negeri Manado

\section{SIMPULAN DAN SARAN}

Politeknik Negeri Manado sebagai sebuah organisasi (legal entity) dan bagian dari masyarakat Indonesia mempunyai tanggungjawab sosial. Tanggungjawab sosial (CSR) tersebut secara eksplisit belum diwajibkan karena tidak diatur dalam undangundang ataupun peraturan yang dikeluarkan pemerintah. Selama ini CSR belum dikenal dalam lingkungan kampus walaupun pada kenyataannya politeknik telah melakukan aktivitas tanggungjawab sosialnya. Stakeholders politeknik meliputi pihak intern dan ekstern. Suatu aktivitas yang dilakukan untuk pihak internal digolongkan sebagai aktivitas tanggungjawab sosial ketika aktivitas tersebut tidak dilakukan dalam rangka memenuhi hak dasar (sesuai yang distandarkan) dari pihak intern. Aktivitas tanggungjawab sosial yang dilakukan untuk pihak ekstern mencerminkan kontribusi/kepedulian politeknik dalam kehidupan sosial bermasyarakat. Politeknik Negeri Manado bertindak sebagai mitra dalam pelaksanaan CSR dari perusahaan dan sebagai pelaku kegiatan tanggungjawab sosial. Sebagai pelaku, tanggungjawab sosial politeknik ditujukan kepada pihak intern dan pihak ekstern. Pelaksanaan tanggungjawab sosial tersebut bagi pihak ekstern salah satunya melalui perwujudan Tridharma ketiga yaitu pengabdian kepada masyarakat. Politeknik juga melakukan kegiatan tanggungjawab sosial terhadap lingkungan.

Politeknik Negeri Manado menjadi mitra dari Bank BRI dalam program CSR BRI peduli pendidikan. Kegiatan Tanggungjawab sosial secara rutin untuk pihak intern berupa pemberian beasiswa prestasi akademik, beasiswa bidik misi dan bantuan penyelesaian studi S2 dan S3. Kegiatan yang tidak rutin meliputi pelatihan bahasa Inggris bagi mahasiswa, bantuan dana bagi dosen untuk mengikuti pelatihan dalam bidang keahlian tertentu, kerjasama studi luar negeri bagi mahasiswa, bantuan sertifikasi kompetensi bagi mahasiswa. Untuk kegiatan ekstern secara rutin dilakukan pengabdian kepada masyarakat dalam bentuk program fisik, non fisik, pelatihan, bantuan sosial juga membuka lapangan kerja bagi masyarakat sekitar kampus, membuat website Polimdo. Kegiatan tidak rutin bagi pihak ekstern meliputi jasa konsultasi ISO, community service, community development dan bakti sosial. Untuk menjaga kelestarian lingkungan dilakukan kegiatan penanaman pohon. Aktivitas tanggungjawab sosial politeknik didasari pada aspek sosial dan lingkungan. 
Laporan keuangan dan laporan akuntabilitas kinerja instansi pemerintah menjadi alat komunikasi dan sarana pertanggungjawaban tanggungjawab sosial Politeknik Negeri Manado. Laporan kegiatan dan laporan penggunaan dana menjadi laporan pendukung dari laporan keuangan dan laporan akuntabilitas kinerja instansi pemerintah. Dana tanggungjawab sosial mengikuti penganggaran yang dilakukan Politeknik Negeri Manado. Penggunaan dana kegiatan tersebut dilaporkan dalam laporan keuangan khususnya laporan realisasi anggaran pada pos belanja barang dan bantuan sosial. Untuk mendukung eksistensi alam, institusi pendidikan tinggi dapat melakukan upaya-upaya untuk menjaga kualitas lingkungan kerja di institusi dan kualitas lingkungan hidup disekitar institusi. Dalam meningkatkan kualitas lingkungan kerja, pimpinan dapat menerapkan budaya kerja 5S (seiri, seiton, seiso, seiketsu dan shitsuke; teknik berumahtangga praktis) sebagai dasar bagi keseluruhan aktivitasnya. Institusi juga dapat mengurangi penggunaan kertas (paperless), menghemat penggunaan listrik dan air serta dapat menerapkan zona bebas rokok dengan menyediakan area khusus untuk para perokok. Peningkatan kualitas lingkungan di sekitar institusi dapat dilakukan melalui program pengolahan limbah air secara sederhana.

Kedepannya, ketika institusi pendidikan tinggi telah berkomitmen untuk menjadikan tanggungjawab sosial sebagai bagian dari visi dan misinya, maka institusi dapat membuat laporan tanggungjawab sosial atau laporan keberlanjutan. Dalam laporan tersebut dapat dideskripsikan secara jelas seluk beluk tanggungjawab sosial termasuk targettarget apa yang akan dicapai dan apa yang sudah dicapai. Penelitian ini hanya dilakukan pada satu situs penelitian karena adanya keterbatasn waktu penelitian. Kedepannya untuk mengembangkan konsep tanggung jawab sosial di institusi pendidikan tinggi dapat dilakukan penelitian dengan membandingkan konsep dan implementasi tanggungjawab sosial dari beberapa institusi. Hasil perbandingan tersebut akan menunjukkan keunikan dari masing-masing institusi dalam tanggungjawab sosialnya. Keunikan yang ada tersebut dapat memperkaya khazanah ilmu pengetahuan di bidang tanggungjawab sosial bahkan dapat dijadikan acuan untuk membangun model atau konsep tanggungjawab sosial institusi pendidikan tinggi. Hasil penelitian ini juga membuka peluang bagi penelitian yang akan datang dalam mendesain laporan tanggungjawab sosial institusi pendidikan tinggi.

\section{DAFTAR PUSTAKA}

Ahmad, J. 2012. Can A University Act as A Corporate Social Responsibility (CSR) Driver? An Analysis. Social Responsibility Journal 8(1): 77-86.

Alvarez, A. W dan Mercedes Ruiz Lazano. 2012. University Social Responsibility (USR) in The Global Context: An Overview of Literature. Business $\mathcal{E}$ Professional Ethics Journal 31: 3-4.

Baried, A. B., N. Septarini, dan W. I. Rahman. 2012. "Analisis Pengaruh Kebijakan Campus Social Responsibility terhadap Kesejahteraan Masyarakat Sekitar (Studi Kasus Tiga Perguruan Tinggi Negeri di Surabaya)." Prosiding Seminar dan Konferensi Nasional Manajemen Bisnis, tanggal 26 Mei 2012: 142-149.

Brundtland, G. H. 1987. Report of The World Comission on Environment and Development: Our Common Future. www.undocuments.net/our-common-future. pdf. Diunduh pada tanggal 28 Agustus 2016 pukul 20.00.

Commission of The European Communities. 2001. Green Paper: Promoting a European Framework for CSR. www. eur-lex.europa.eu/LexUriServ.

Diunduh pada tanggal 14 Agustus 2016 pukul 16.00

Dahlia, L. dan S. V. Siregar. 2008. "Pengaruh Corporate Social Responsibility terhadap Kinerja Perusahaan (Studi Empiris pada Perusahaan yang Tercatat 
di Bursa Efek Indonesia pada tahun 2005 dan 2006)." Simposium Nasional Akuntansi 11.

Davis, S. A., T. H. Edmister, K. Sullivan dan C. K. West 2003. Educating Sustainable Societies for the Twenty-first Century. International Journal of Sustainability in Higher Education 4(2): 169-179.

Departemen Keuangan Republik Indonesia. Kewajiban Penyampaian Laporan Tahunan bagi Emitten atau Perusahaan Publik. Badan Pengawas Pasar Modal dan Lembaga Keuangan. Kep-134/BL/2006.

Dima, A. M., S. Vasilache, V. Ghinea dan S. Agoston. 2013. A Model of Academic Social Responsibility. Review of Administrative Sciences: $23-43$.

Filho, J. M. de S., L. S. O. Wanderley, C. P. Gomez dan F. Farache. 2010. Strategic Corporate Social Responsibility Management for Competitive Advantage. Brazilian Administration Review 7(3): 294309.

Freeman, R. E. dan W. M. Evan. 1988. A Stakeholder Theory of the Modern Corporation: Kantian Capitalism in Tom L. Beauchamp and Norman Bowie, ed, Ethical Theory and Business, third edition, Englewood Cliffs. NJ: Prentice Hall.

Kotler, P. dan N. Lee. 2011. Corporate Social Responsibility: Doing the Most Good for Your Company and Your Cause. John Wiley and Sons, Inc. New Jersey.

Miles, M. B. dan A. M. Huberman. 1992. Analisis Data Kualitatif. Terjemahan Tjetjep Rohendi Rohidi. UI-Press. Jakarta.

Muijen, H. 2004. Corporate Social Responsibility Starts at University. Journal of Business Ethics 53(1-2): 235-246.

Nejati, M., A. Shafei, Y. Zalamsadeh dan M. Daraei. 2011. Corporate Social Responsibility and Universities: A Study of Top 10 World Universities' Website. African Journal of Business Management 5(2): 440447.

Peraturan Menteri Riset, Teknologi, dan Pendidikan Tinggi Republik Indonesia
Nomor 44 Tahun 2015 tentang Standar Nasional Pendidikan Tinggi.

Politeknik Negeri Manado, 2014. Laporan Kegiatan Pengabdian kepada Masyarakat.

---------, 2015. Laporan Kegiatan Pengabdian kepada Masyarakat.

---------, 2015. Laporan Keuangan.

--_----, 2015. Laporan Akuntabilitas Kinerja Instansi Pemerintah.

Porter, M. E. dan M. R. Kramer. 2006. Strategy and Society: The Link Between Competitive Advantage and Corporate Social Responsibility. Harvard Business Review, December R0612D, 1-15.

Rumambi, H. D. 2014a. Konsep Tanggungjawab Sosial Perusahaan dalam Perspektif Ajaran Sosial Gereja Katolik. Studipada PT. Indofood CBP Sukses Makmur Tbk cabang Manado. Disertasi.Universitas Brawijaya.

Rumambi, H. D., I. Triyuwono, G. Irianto, dan A. Djamhuri. 2014b. Love-Based Corporate Social Responsibility (CSR): A Christian Perspective. International Journal of Business and Behavioral Sciences 4(5): 24-42.

Rumambi, H. D. 2016. The Implementation of Corporate Social Responsibility (CSR) in The Light of Common Good. Research Journal of Finance and Accounting 7(20): 100-107.

Shawyun, T. 2011. "From Corporate Social Responsibility (CSR) to University Social Responsibility (USR)" in AsiaEurope Foundation's ASEM Education Hub and the University of Innsbruck: University and Their Social Responsibilities. $2^{\text {nd }}$ Asia-Europe Education Workshop, 5-7 June 2011, InnsbruckAustria.

Shriberg, M. 2002. Institutional Assessment Tools for Sustainability in Higher Education: Strengths, Weaknesses and Implications for Practice and Theory. International Journal of Sustainability in Higher Education 10(1): 68-82. 
Smith, A. D. 2007. Making The Case for The Competitive Advantage of Corporate Social Responsibility. Business Strategy Series 8(3): 186-195.

Solihin, I. 2011. Corporate Social Responsibility from Charity to Sustainability. Salemba Empat. Jakarta.

Subagyo dan A. P. B. Silalahi. 2014. "Implementasi Tanggungjawab Sosial Perguruan Tinggi dan Dampaknya terhadap Citra Kampus di Universitas Nusantara PGRI Kediri." Nusantara of Research 1(2): 192-205.

Sukoharsono, E. G. 2006. “Alternatif Riset Kualitatif Sains Akuntansi: Biografi, Phenomenologi, Grounded Theory, Critical Etnografi dan Case Study." Dipublikasikan di Analisa Makro dan Mikro: Jembatan Kebijakan Ekonomi Indonesia. Editor: Khusnur Ashar, Gugus Irianto dan Nanang Suryadi. Hal. 230245. BPFE Universitas Brawijaya.

Taylor, S. J., R. Bogdan dan M. L. DeVault. 2016. Introduction to Qualitative Research
Methods-A Guidebook and Resource. $4^{\text {th }}$ Edition. John Wiley \& Sons, Inc. New Jersey.

Topal, R. S. 2009. "CSR in Universities Around the World." Social Responsibility Research Network. Discussion Papers in Social Responsibility, No. 0902: 1-23. www.socialresponsibility.biz.

Undang-Undang Republik Indonesia No. 40 Tahun 2007 tentang Perseroan Terbatas. Undang-Undang Republik Indonesia No. 32 tahun 2009 tentang Perlindungan dan Pengelolaan Lingkungan Hidup.

Undang-Undang Republik Indonesia No. 12 tahun 2012 tentang Pendidikan Tinggi.

Vallaeys, F. 2013. Defining Social Responsibility: A Matter of Philosophical Urgency for University. Global University Network for Innovation. http:/ / www.guninetwork.org/articles/defini ng-social-responsibility-matter-philoso phical-urgency-universities. Diunduh pada tanggal 19 Juli 2017 pukul 19.00. 